\title{
Lactic Acid Bacteria as Biological Control of Staphylococcus aureus in Coalho Goat Cheese
}

\section{Rânmilla Cristhina Santos Castro, Anay Priscilla David de Oliveira, Eline Almeida Rodrigues de Souza, Tayla Marielle Antunes Correia, Jane Viana de Souza and Francesca Silva Dias*}

Federal University of San Francisco Valley, Rod. BR 407, Km 12, Lote 543, Projeto de Irrigação Senador Nilo Coelho, s/no, C1, BR-56.300-990 Petrolina, Pernambuco, Brazil

Received: 21 February 2018 Accepted: 23 May 2018

\section{(c) (i) ()ㅜ}

*Corresponding author:

Phone: +558721014839;

E-mail: francesca.nobre@univasf.edu.br

ORCID IDs: 0000-0002-2325-8958 (Castro), 0000-0003-2356-4311 (Oliveira), 0000-0003-4100-9936 (Souza, EAR), 0000-0002-6909-264X (Correia), 0000-0001-6918-5179 (Souza, JV), 0000-0003-0174-4397 (Dias)

\section{SUMMARY}

The aim of this study is to investigate the bacterial population in coalho goat cheese produced in the semi-arid northeast region of Brazil, to analyse the antibiotic resistance profiles of the identified pathogenic bacteria, to detect the staphylococcal enterotoxin genes and to evaluate the addition of autochthonous lactic acid bacteria (LAB) with technofunctional properties for the control of Staphylococcus aureus growth. In the analysed samples, strains of Escherichia coli ( $N=11)$, Salmonella spp. $(N=18)$, Listeria spp. $(N=6)$ and $S$. aureus $(N=9)$ were classified as multidrug resistant $(M D R)$. The most commonly isolated pathogen from the studied coalho goat cheese was $S$. aureus. Its isolates were positive for the genes encoding enterotoxins $A(s e a), B(s e b), C(s e c)$ and $D$ (sed). The autochthonous $L A B$ with the potential to inhibit $S$. aureus were identified as Enterococcus faecium. These strains were selected for in vitro tests of protective, safety, technological and functional properties. In the coalho goat cheese food matrix, these selected autochthonous LAB were able to reduce the enterotoxigenic MDR S. aureus load by approx. 3 log units.

Key words: coalho goat cheese, pathogens, multidrug resistance, staphylococcal enterotoxins, microbiological safety, technofunctional properties of Enterococcus faecium

\section{INTRODUCTION}

Brazil is the largest producer of goat's milk in South America, and $93 \%$ of the goat population is concentrated in the Northeast region. Goat raising is as a promising activity due to changes in the food supply chain and market diversification. Among the outstanding products of goat's milk, the coalho cheese is a traditional product of Northeast Brazil, usually produced from raw milk and is greatly valued by consumers $(1,2)$. Artisanal cheese is considered part of the cultural context and identity of a region (3).

Although artisanal goat cheese is one of the main products used to generate income for smallholders, it is still primarily handmade, often without suitable facilities. Thus, there is no standardization of the process, and the use of raw milk is common, endangering the health of consumers (2). The absence of quality control standards for goat's milk and dairy products in Brazil is a major hindrance to agribusiness specializing in dairy goats. The market access to these products depends strongly on the application of appropriate technology to obtain the quality standards required by legislation (4).

Regarding the microbiological risks of goat cheese, in general, artisanal cheese produced from goat's milk has poor microbial quality (5). Staphylococcus aureus is one of the most important foodborne pathogens in cheese due the manual contact of the handlers during the manufacture of the product $(6,7)$. Tools to increase the microbiological safety of artisanal goat cheese would include the addition of specific antibacterial starter cultures, such as selected lactic acid bacteria (LAB) with anti-Staphylococcus activity. The incorporation of these cultures in the technological procedures for product preparation is crucial, not only to increase microbiological safety by inhibiting pathogens but also to improve the technological and functional properties and enhancement of the cheese flavour, important attributes for dairy derivatives of goat origin (8).

For the semi-arid northeastern region of Brazil, it is a fundamental necessity to characterize the microbiology of handmade goat cheese to increase the microbiological and technological quality of the product. This is because of the possibility of required registration 
for the geographical indication (IG) by the Ministry of Agriculture, Livestock and Supply (MAPA, Brazil), which is regulated through Normative Instruction (NI) no. 30 of 7 August 2013 (9). This $\mathrm{NI}$ allows that the artisan cheese traditionally produced from raw milk can be matured for less than sixty days when technical and scientific studies prove that a reduction of the maturation period does not affect the safety of the product. Additionally, the smallholders will be able to cater to the food acquisition program (Programa de Aquisição de Alimentos, PAA, Brazil), a programme in which the Brazilian government acquires food products from goat breeding to supply day-care centres, hospitals and other institutions with government assistance. Thus, this study aims to investigate bacterial microorganisms in coalho goat cheese produced in the Brazilian semi-arid northeast region by analysing the resistance profile of the pathogens, by detecting the enterotoxin genes in the multidrug-resistant (MDR) S. aureus isolates and by evaluating the addition of autochthonous LAB for controlling S. aureus isolate of the goat cheese.

\section{MATERIALS AND METHODS}

\section{Sample collection}

A total of 40 small-scale commercially produced coalho goat cheese samples were acquired from goat farmer associations in eight municipalities in the semi-arid northeast region of Brazil in the state of Pernambuco and Bahia, comprising: Petrolina, Santa Maria da Boa Vista, Lagoa Grande, Cabrobó, Dormentes, Afrânio, Casa Nova and Sento Sé (Fig. 1). Five samples were analysed from each city, and samples were transported to the laboratory in isothermal boxes under refrigeration and analysed immediately.

\section{Microbiological analysis and determination of $\mathrm{pH}$}

A total of $25 \mathrm{~g}$ of each goat cheese sample was removed by means of radial cuts and placed in sterile plastic bags containing $225 \mathrm{~mL}$ of a sterile $2 \%(\mathrm{~m} / \mathrm{V})$ sodium citrate (Synth, Diadema, Brazil) solution and homogenized for 2 min in a Stomacher $^{\circledR}$ (Mayo Homogenius HG 400; São Paulo, Brazil). Tenfold

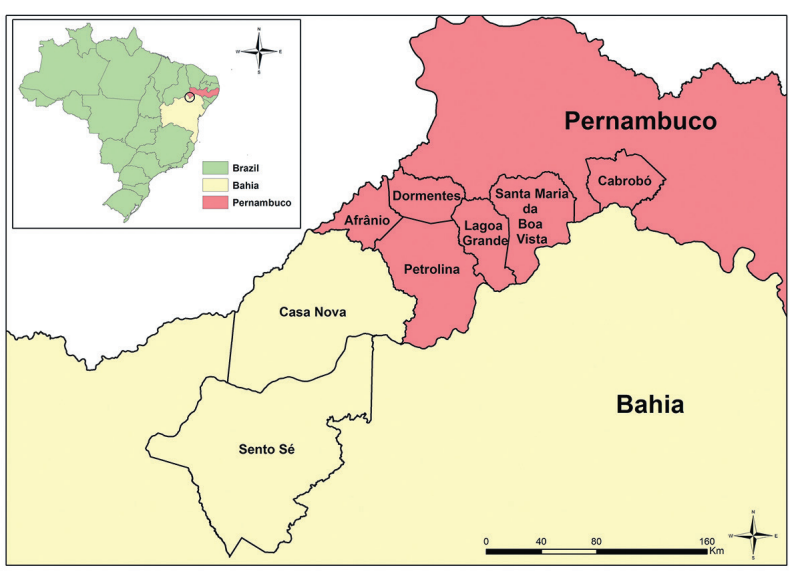

Fig. 1. Map of the municipalities of Bahia and Pernambuco (northeast region, Brazil) where the coalho goat cheese samples were collected dilutions $\left(10^{-1}\right.$ to $\left.10^{-10}\right)$ of cheese homogenate were prepared in $0.1 \%$ sterile peptone water (HiMedia, Bombay, India) and plated on specific medium to detect mesophilic aerobic bacteria (MAB), lactic acid bacteria (LAB), thermotolerant coliforms and Escherichia coli, Staphylococcus aureus, Salmonella spp. and Listeria monocytogenes.

The MAB and $L A B$ were enumerated on plate count agar (PCA, HiMedia) and de Man, Rogosa and Sharpe agar (MRS, HiMedia), respectively. Plates were incubated at $37^{\circ} \mathrm{C}$ for 48 $\mathrm{h}$ for MAB and 72-96 $\mathrm{h}$ for $L A B$. The characterization of the $L A B$ isolates included Gram staining (Gram Staining Kit, Laborclin, São Paulo, Brazil), morphology, catalase (Anidrol, Diadema, Brazil), motility (HiMedia) and cytochrome oxidase activities (Probac, São Paulo, Brazil). One isolate was stored from each goat cheese sample.

For the enumeration of thermotolerant coliforms and detection of E. coli, the Fluorocult ${ }^{\circledR}$ broth (Merck, Darmstadt, Germany) was used (10). The tubes were incubated at $37^{\circ} \mathrm{C}$ for $24 \mathrm{~h}$. Positive tubes, after the addition of Kovac's reagent (Probac), served for calculation of the most probable number (MPN). For confirmation of E. coli, Gram-negative (Gram Staining Kit, Laborclin), oxidase-negative (Probac) and catalase-positive (Anidrol) colonies were streaked on PCA and incubated at $37^{\circ} \mathrm{C}$ for $24 \mathrm{~h}$ to perform the indole (tryptone broth, HiMedia), methyl red and Voges-Proskauer (MR-VP medium, HiMedia) and citrate (Simmons citrate agar, HiMedia) (IMViC) biochemical tests.

S. aureus colonies were isolated, identified and confirmed biochemically according to Normative Instruction no. 62 (11). Aliquots of $0.1 \mathrm{~mL}$ of each cheese sample were plated onto the surface of Baird-Parker agar (HiMedia) in duplicate and incubated at $37^{\circ} \mathrm{C}$ for $24-48 \mathrm{~h}$. For the identification, the following tests were conducted for typical colonies selected from the medium: Gram staining, catalase, coagulase (Laborclin), oxidation and fermentation of glucose and mannitol (Synth), as well as the detection of DNAse and thermonuclease (DNase test agar with Toluidine Blue, HiMedia) activities.

Salmonella spp. were detected according to the method of Pignato et al. (12). Tetrathionate broth (HiMedia) supplemented with iodine and Brilliant Green solutions and Rambach agar (Merck) was used for selective enrichment ( $18 \mathrm{~h}$ at $37^{\circ} \mathrm{C}$ ) and isolation $\left(24 \mathrm{~h}\right.$ at $37^{\circ} \mathrm{C}$ ), respectively. For biochemical identification (11), typical colonies were added into tubes containing triple sugar iron (TSI) agar (HiMedia) or lysine iron agar (LIA; HiMedia) and incubated at $37^{\circ} \mathrm{C}$ for $24 \mathrm{~h}$. Presumptive Salmonella strains were checked for differential Gram staining, catalase and oxidase activity, motility, and sulphide and indole production (HiMedia). In addition, serological tests were performed using somatic and flagellar polyvalent antiserum (Probac) following the manufacturer's instructions.

Detection of $L$. monocytogenes was detected as described by Capita et al. (13). Fraser broth (HiMedia) and Palcam agar (HiMedia) were used for selective enrichment $\left(24-48 \mathrm{~h}\right.$ at $\left.35^{\circ} \mathrm{C}\right)$ and isolation ( $24-48 \mathrm{~h}$ at $35^{\circ} \mathrm{C}$ ), respectively. Suspected Listeria spp. colonies were streaked onto tryptone soy agar (TSA) plates 
supplemented with $0.6 \%$ yeast extract (TSA-YE; HiMedia) and incubated at $37^{\circ} \mathrm{C}$ for $24-48 \mathrm{~h}$. Next, appropriate biochemical tests were conducted on Gram-positive isolates to verify the production of catalase, fermentation of carbohydrates, haemolysis on sheep blood agar (HiMedia) and motility at $25^{\circ} \mathrm{C}$.

For quantitative analyses, plates with 30-300 colonies were counted. The microbiological counts were expressed in logarithms of the number of colony forming units per gram (CFU/g). In qualitative analyses (detection of Salmonella spp. and L. monocytogenes), microorganisms were detected as being present or absent.

For the determination of $\mathrm{pH}$, cheese (10 g) was homogenized in $10 \mathrm{~mL}$ of distilled water according to de Almeida Júnior et al. (14). The analyses were performed in triplicate with a $\mathrm{pH}$ meter (PHS-3E-Bl; lon, Araucária, Brazil).

\section{Antimicrobial resistance of pathogens}

The antibiotic resistance of isolated pathogens was determined using disc diffusion method on Mueller-Hinton agar with Multidiscos Gram Negativo $12^{\circledR}$ and Multidiscos Gram Positivo $12^{\circledR}$ (Laborclin) (Table 1). After incubation at $37^{\circ} \mathrm{C}$ for $24 \mathrm{~h}$, inhibition zone diameters were measured following the recommendations of the Clinical and Laboratory Standards Institute (15). The multidrug resistance profiles were calculated by the index of multiple antibiotic resistance (MAR). Strains with an index equal to or above 0.5 and resistant to three or more tested antimicrobials were classified as having a high MAR index (16).

\section{Molecular identification of pathogens and} detection of genes for staphylococcal enterotoxins

The DNA of pathogens (two of each genus) with the highest MAR index and of those resistant to three or more tested antimicrobials was extracted using a PureLink Genomic DNA Mini Kit (Invitrogen, Carlsbad, CA, USA) following the manufacturer's instruction. The polymerase chain reaction (PCR) was performed according to the protocol proposed by de Ávila et al. (17).

For the $S$. aureus strains with the highest MAR index, genes coding for the classical staphylococcal enterotoxins (SEs: sea, seb, sec, sed and see) were detected as described by Schneid Kroning et al. (18). The positive controls used in the reactions for the classic enterotoxin genes were donations of Oswaldo Cruz Foundation (FIOCRUZ, Rio de Janeiro, Brazil), strains were from the National Institute for Quality Control in Health (INCQS, Rio de Janeiro, Brazil): S. aureus INCQS 00285 (sea and sed), S. aureus INCQS 00005 (seb), S. aureus INCQS 00080 (sec) and S. aureus INCQS 00093 (see).

\section{Antimicrobial activity of autochthonous $L A B$ against $S$. aureus strain from coalho goat cheese}

The inhibitory effect of autochthonous LAB against $S$. aureus strain QCSA24 (enterotoxigenic and MDR isolate with the greatest MAR index) from coalho goat cheese was tested using the agar disc diffusion method according to Ferrari et al. (19) with modifications. The suspension of the S. aureus

Table 1. Antimicrobial agent discs* used to evaluate the resistance of pathogens and lactic acid bacteria isolated from coalho goat cheese

\begin{tabular}{|c|c|c|c|}
\hline Microorganism & Antimicrobial class & Antimicrobial agent & (m(antimicrobial agent)/ $\mu \mathrm{g}) /$ disc \\
\hline \multirow[t]{12}{*}{ Gram-negative } & penicillins & ampicillin & 10 \\
\hline & fluoroquinolones & ciprofloxacin & 5 \\
\hline & folate pathway inhibitors & sulfazotrim & 25 \\
\hline & aminoglycosides & gentamycin & 10 \\
\hline & & amikacin & 20 \\
\hline & cephems & cephalothin & 30 \\
\hline & & ceftazidime & 30 \\
\hline & & cefepime & 30 \\
\hline & & cefoxitin & 30 \\
\hline & & cefuroxime & 30 \\
\hline & $\beta$-lactamase inhibitor combinations & amoxicillin+clavulanate & 30 \\
\hline & carbapenems & meropenem & 10 \\
\hline \multirow[t]{12}{*}{ Gram-positive } & penicillins & penicillin & 10 \\
\hline & & oxacillin & 1 \\
\hline & fluoroquinolones & ciprofloxacin & 5 \\
\hline & folate pathway inhibitors & sulfazotrim & 25 \\
\hline & aminoglycosides & gentamycin & 10 \\
\hline & cephems & cefepime & 30 \\
\hline & tetracyclines & tetracycline & 30 \\
\hline & glycopeptides & vancomycin & 30 \\
\hline & phenicols & chloramphenicol & 30 \\
\hline & lincosamides & clindamycin & 2 \\
\hline & macrolides & erythromycin & 15 \\
\hline & ansamycins & rifampin & 5 \\
\hline
\end{tabular}

${ }^{*}$ Multidiscos Gram Negativo $12^{\circledR}$ and Multidiscos Gram Positivo $12^{\circledR}$ (Laborclin) 
strain containing $10^{8} \mathrm{CFU} / \mathrm{mL}$ was uniformly spread with sterile swab over the plate with brain heart infusion (BHI; HiMedia) agar. Whatman no. 1 filter paper discs (Sigma-Adrich, Merck, St. Louis, MO, USA) of $6 \mathrm{~mm}$ impregnated with $20 \mu \mathrm{L}$ cell-free supernatant obtained by centrifugation (centrifuge K14-1215; Kasvi, São José dos Pinhais, Brazil) at 2500×g for $10 \mathrm{~min}$ from each isolate of autochthonous LAB were placed onto the surface of the agar. The $\mathrm{pH}$ of the cell-free supernatant was adjusted to 6.5 ( $1 \mathrm{mmol} / \mathrm{L} \mathrm{NaOH})$. After incubation at $37{ }^{\circ} \mathrm{C}$ for $24 \mathrm{~h}$ the radius ( $\mathrm{mm}$ ) of inhibition zones around the discs was measured. Inhibition zones smaller than $1 \mathrm{~mm}$ radius were considered negative. The experiment was performed in triplicate. Six autochthonous $L A B$ with the highest antimicrobial activity against $S$. aureus strain were selected for additional tests described below.

\section{Antimicrobial activity among and molecular identification of autochthonous $L A B$}

A test was performed to observe the antimicrobial activity among autochthonous $\mathrm{LAB}(20)$. In this assay, $L A B$ strains were grown on MRS broth at $37^{\circ} \mathrm{C}$ for $24 \mathrm{~h}$. An aliquot of $1 \mathrm{~mL}$ of the LAB isolate (approx. $10^{6} \mathrm{CFU} / \mathrm{mL}$, final concentration) and $15 \mathrm{~mL}$ of MRS broth (HiMedia) were inoculated onto the plate using the pour plate method. An aliquot of $10 \mu \mathrm{L}$ of another LAB isolate was spotted onto MRS agar and incubated for $24 \mathrm{~h}$ at $37^{\circ} \mathrm{C}$. The detection of a zone of inhibition in the lawn indicated that there was an antagonistic action among the LAB isolates. The experiment was performed in triplicate.

The molecular identification of the six $L A B$ strains was done in the same way as for pathogens.

\section{Safety, technological and functional properties of autochthonous $L A B$}

Phenotypical tests to identify virulence activity of autochthonous LAB were performed, including haemolytic activity (14), production of DNase and ability to coagulate rabbit plasma (19). The resistance of $L A B$ strains to antimicrobial agents (Table 1) was tested by the agar disc diffusion test using Multidiscos Gram Positivo $12^{\circledR}$ (Laborclin) (15).

As probiotic candidates, the six autochthonous LAB strains were tested in solutions that chemically simulate physiological conditions. The survival rate of $\mathrm{LAB}$ at $\mathrm{pH}=2$ and in bile salt ( $2 \%$ ) conditions was calculated by determining the total viable counts at time 0 and $3 \mathrm{~h}$ on MRS agar according to de Almeida Júnior et al. (14). In addition, the proteolytic (14) and $\beta$-galactosidase (19) activities of autochthonous LAB were checked. To verify proteolytic activity, the strains were plated on skimmed milk agar (HiMedia) and incubated at $7{ }^{\circ} \mathrm{C}$ for 10 days and $37^{\circ} \mathrm{C}$ for $48 \mathrm{~h}$. A clear halo around the colonies indicated a positive result. For the activity of the $\beta$-galactosidase enzyme, one colony of each isolate was emulsified in the tube containing an ONPG (o-nitrophenyl- $\beta$-D-galactopyranose) disc (Fluka, Buchs, Switzerland) and 1 $\mathrm{mL}$ sterile saline. The tubes were incubated at $37^{\circ} \mathrm{C}$, and the yellow staining (positive reaction) was observed within $6 \mathrm{~h}$. All tests were performed in triplicate.

\section{Control of S. aureus strain by autochthonous $L A B$ in coalho goat cheese}

The artisanal goat cheese (coalho cheese) was produced to evaluate the antibacterial activity of $L A B$ against $S$. aureus. The $L A B$ were inoculated using a mix of the six autochthonous $L A B$ strains isolated from goat cheese (UNIVASF CAP QC1, QC4, QC13, QC14, QC18 and QC19) with highest antimicrobial activity against $S$. aureus strain. The experiment was conducted as proposed by Ferrari et al. (19) with modifications in the use of pathogen and inoculum concentration. This study used a pathogen $S$. aureus isolated from goat cheese (QCSA24, an enterotoxigenic MDR S. aureus isolate). The first cheese sample (SA, positive control) was inoculated with $S$. aureus, suspended in $1 \%$ milk in the concentration of $10^{8} \mathrm{CFU} /$ $\mathrm{mL}$. The second cheese sample $(\mathrm{SA}+\mathrm{LAB})$ was inoculated with the same concentration of $10^{8} \mathrm{CFU} / \mathrm{mL}$ of $S$. aureus and the mix of six selected $E$. faecium strains. The third cheese sample (NC) served as negative control, without the addition of microorganisms. The artisanal goat cheese was drained and placed in perforated moulds $(250 \mathrm{~g})$. Three replicate determinations for each cheese were carried out. The cheese samples were packed in sterile plastic bags and stored at $10^{\circ} \mathrm{C}$ for 20 days. The bacteriological analyses (S. aureus and LAB) and $\mathrm{pH}$ measurements were conducted in five five-day intervals (days $0,5,10,15$ and 20) in triplicate.

\section{Statistical analysis}

SISVAR ${ }^{\circledR}$ software v. $5.6(21)$ helped to statistically analyse the antimicrobial activities of autochthonous LAB against $S$. aureus isolate in goat cheese. The results were evaluated using ANOVA and the mean values were compared by a ScottKnott test (22). Quantitative data were analysed by regression. A probability value at $\mathrm{p}<0.05$ was statistically significant.

\section{RESULTS AND DISCUSSION}

\section{Microbiological quality and $\mathrm{pH}$ value of coalho goat cheese}

According to the Brazilian Technical Regulation of Identity and Quality, coalho cheese is obtained by the coagulation of milk by rennet, complemented or not by the action of selected $L A B$, stored under an average temperature of $10-12^{\circ} \mathrm{C}$ and normally marketed up to ten days after manufacture (23). In addition, according to the Brazilian legislation, it is a product of medium to high humidity, of semi-cooked curd or cooked or otherwise prepared from raw curd (unheated) (23). The goat cheese samples collected in this study were prepared from raw curd (unheated) and had high humidity.

Total counts of MAB and $L A B$ in the cheese remained at 6.7 and $6.6 \mathrm{log}$ CFU/g, respectively (Table 2). In general, our results showed a high cell number count compared with those found in other goat cheese varieties that were previously observed 
Table 2. Log enumerations of microbial groups and determination of $\mathrm{pH}$ (mean value \pm standard deviation) of coalho goat cheese commercialized in municipalities of the semi-arid northeast region of Brazil

\begin{tabular}{|c|c|c|c|c|c|}
\hline \multirow{2}{*}{ Municipality } & \multicolumn{3}{|c|}{$N($ microorganism)/(log CFU/g) } & \multirow{2}{*}{$N(\mathrm{TC}) /(\log \mathrm{MPN} / \mathrm{g})$} & \multirow{2}{*}{$\mathrm{pH}$} \\
\hline & MAB & LAB & Staphylococcus aureus & & \\
\hline Petrolina & $6.7 \pm 1.2$ & $6.5 \pm 1.3$ & $6.9 \pm 0.3$ & $6.7 \pm 1.0$ & $5.4 \pm 0.1$ \\
\hline Santa Maria da Boa Vista & $7.6 \pm 0.1$ & $7.0 \pm 0.5$ & $6.7 \pm 0.7$ & $5.7 \pm 3.7$ & $5.7 \pm 0.2$ \\
\hline Lagoa Grande & $6.9 \pm 0.7$ & $6.0 \pm 0.6$ & $5.9 \pm 0.6$ & $3.2 \pm 2.5$ & $5.7 \pm 0.3$ \\
\hline Cabrobó & $6.0 \pm 0.6$ & $6.6 \pm 0.6$ & $6.3 \pm 0.7$ & $1.17 \pm 0.02$ & $5.4 \pm 0.1$ \\
\hline Casa Nova & $7.0 \pm 0.7$ & $7.0 \pm 0.5$ & $5.82 \pm 0.09$ & $1.17 \pm 0.02$ & $5.2 \pm 0.2$ \\
\hline Sento Sé & $6.6 \pm 0.5$ & $7.0 \pm 0.4$ & $5.6 \pm 0.3$ & $1.17 \pm 0.02$ & $5.24 \pm 0.09$ \\
\hline Dormentes & $6.1 \pm 0.7$ & $6.2 \pm 0.4$ & $5.7 \pm 0.2$ & $1.17 \pm 0.02$ & $5.19 \pm 0.06$ \\
\hline Afrânio & $7.1 \pm 0.8$ & $6.8 \pm 1.0$ & $6.8 \pm 0.8$ & $1.17 \pm 0.02$ & $5.3 \pm 0.2$ \\
\hline Average & 6.7 & 6.6 & 6.2 & 2.7 & 5.4 \\
\hline
\end{tabular}

$\mathrm{MAB}=$ mesophilic aerobic bacteria, $\mathrm{LAB}=$ lactic acid bacteria, $\mathrm{TC}=$ thermotolerant coliforms, $\mathrm{CFU}=$ colony forming unit, $\mathrm{MPN}=$ most probable number

in Morocco, Spain and Greece $(24,25)$. Mesophilic lactobacilli are the most important components of the non-starter $L A B$ (NSLAB) microbiota of cheese. These microorganisms can contribute to sensory characteristics and the inhibition of potential pathogens in the product $(25,26)$.

As for the current legislation in Brazil for microbiological criteria of cheese with high moisture content, both the Ministry of Health and the Ministry of Agriculture, through the law RDC 12 (27) and Ordinance 146 (28), respectively, agree that 2 out of 5 samples may contain between 3 and $3.7 \mathrm{log}$ CFU/g thermotolerant coliforms, 2 out of 5 samples may contain between 2 and 3 log CFU/g coagulase-positive staphylococci, while Salmonella spp. and L. monocytogenes must be absent from the product.

In this study, five, three and two samples from the municipalities of Petrolina, Santa Maria da Boa Vista and Lagoa Grande (Pernambuco State, Brazil), respectively, did not conform to the law for thermotolerant coliforms. On average, the population of thermotolerant coliforms was $2.7 \mathrm{log} \mathrm{CFU} / \mathrm{g}$ ( Table 2). The presence of coliforms seems to be usual in raw goat's milk cheese as previously reported (24). Among the 40 samples positive for thermotolerant coliforms, in 11 samples there was phenotypic confirmation of E. coli (Table 3).
Regarding the presumptive enumeration of $S$. aureus, the overall average in the municipalities was $6.2 \mathrm{log}$ CFU/g (Table 2). It was noticeable that the population of LAB and Staphylococcus was similar in the goat cheese samples, both in the range of $6 \log$ CFU/g. The counts of Staphylococcus were higher than recommended by law (Table 2 ) in all the samples. In the biochemical identification (Table 3), 13 isolates were confirmed as coagulase-negative Staphylococcus, 18 as coagulase-positive Staphylococcus and 9 as S. aureus.

S. aureus is one of the most common pathogens associated with raw milk cheese. It presents a microbiological safety concern only when it is present at a level higher than 4 log CFU/g and when strains can produce enterotoxins. Generally, the amount of staphylococcal enterotoxins for the establishment of typical symptoms of food poisoning ranges from $20 \mathrm{ng}$ to $1 \mu \mathrm{g}(29)$.

Salmonella spp. were detected in 18 samples of goat cheese ( $45 \%$; Table 3). Salmonella can originate from goat's milk, utensils and equipment, and improper handling during the production of cheese. Salmonella spp. survive for extensive periods in goat cheese and represent a potential health hazard. Outbreaks of infections with Salmonella spp. have been associated with the consumption of cheese (30). In Brazil there is little

Table 3. Biochemical confirmation and multiple antibiotic resistance (MAR) index $(\geq 0.5)$ of pathogens isolated from coalho goat cheese commercialized in municipalities of the semi-arid northeast of Brazil

\begin{tabular}{|c|c|c|c|c|c|c|}
\hline \multirow[b]{2}{*}{ Municipality } & \multicolumn{6}{|c|}{ Number of isolates } \\
\hline & Escherichia coli & CNS & CPS & Staphylococcus aureus & Salmonella spp. & $\begin{array}{l}\text { Listeria } \\
\text { spp. }\end{array}$ \\
\hline Petrolina & 1 & 5 & n.d. & n.d. & 5 & 1 \\
\hline Santa Maria da Boa Vista & n.d. & 2 & 1 & 2 & 5 & n.d. \\
\hline Lagoa Grande & 3 & 2 & 2 & 1 & 2 & 2 \\
\hline Cabrobó & 3 & n.d. & 3 & 2 & 2 & 1 \\
\hline Casa Nova & 4 & n.d. & 4 & 1 & n.d. & 1 \\
\hline Sento Sé & n.d. & n.d. & 4 & 1 & n.d. & 1 \\
\hline Dormentes & n.d. & 1 & 2 & 2 & 1 & n.d. \\
\hline Afrânio & n.d. & 3 & 2 & n.d. & 3 & n.d. \\
\hline Total number of isolates & 11 & 13 & 18 & 9 & 18 & 6 \\
\hline $\begin{array}{l}\text { Number of isolates with MAR } \\
\text { index } \geq 0.5\end{array}$ & 8 & n.d. & n.d. & 9 & 12 & 6 \\
\hline
\end{tabular}

CNS=coagulase-negative Staphylococcus, CPS=coagulase-positive Staphylococcus, n.d.=not detected 
information about the prevalence of Salmonella spp. in goat's milk and its derivatives. Oliveira et al. (4) reported the presence of $S$. enterica in samples of milk on dairy goat farms from the Cariri region in the northeastern state of Paraiba, Brazil.

L. monocytogenes was detected in six samples of goat cheese (15\%; Table 3), which is a major concern for consumers of this product in the region. Brazilian law does not tolerate the presence of $L$. monocytogenes in food products. EI Galiou et al. (24) reported the presence of this pathogen in samples of goat cheese. According to Melo et al. (31), L. monocytogenes is a challenging issue for the dairy industry. Cheese offers a suitable environment for this pathogen, which is also persistent in dairy processing plants.

The average $\mathrm{pH}$ value of cheese collected from different municipalities in this study ranged from 5.2 to 5.7 , and the overall average was 5.4 (Table 2). In the Brazilian legislation, the $\mathrm{pH}$ of goat's milk is slightly less acidic than of cow's milk (32). However, different factors, such as autochthonous microbiota, chemical composition, renneting parameters, ripening time and traditional technology can affect the $\mathrm{pH}$ of the cheese.

\section{Antimicrobial resistance test and MAR index}

The antimicrobial resistance profile calls attention to the high MAR index of pathogens. In our study, there were pathogens that had MAR indices higher than 0.5 and were resistant to three or more antimicrobials. Among the 11 isolates of $E$. coli, eight had MAR indices higher than 0.5 (Table 3). Twelve Salmonella spp. isolates had MAR indices higher than or equal to 0.50 (Table 3), while six isolates of Listeria spp. were classified as MDR (Table 3). One isolate of S. aureus from the municipality of Casa Nova (QCSA24) had the greatest MAR index 0.91 , followed by the isolate from the municipality of Dormentes (QCSA34), with MAR index 0.83 (data not shown).

All S. aureus isolates proved to be resistant to three or more classes of antimicrobial agents and had a MAR index higher than or equal to 0.50 (Table 3). The coagulase-negative
Staphylococcus and coagulase-positive Staphylococcus strains had MAR indices lower than 0.5 (Table 3). These results showed that raw milk cheese may act as vehicle for the transmission of MDR strains of pathogens, and thus constitutes a potential risk for public health. Consumers should avoid the consumption of raw milk cheese of poor microbiological quality.

\section{Identification of pathogens and presence of S. aureus enterotoxin genes}

Two isolates of each genus with the highest MAR index that were resistant to three or more tested antimicrobials were biochemically identified as E. coli (QCE15 and QCE18). Salmonella spp. (QCS5 and QCS7), Listeria spp. (QCL5 and QCL19) and S. aureus (QCSA24 and QCSA34) were also identified molecularly. The identification by $16 \mathrm{~S}$ rRNA gene sequencing presented $99 \%$ similarity with E. coli (GU594316.1/GU811877.1), Salmonella Typhi (DQ480723.1), S. aureus (NR_037007.1/ NR_113956.1) and L. monocytogenes (NR_044823.1). These pathogens have been reported in goat cheese $(24,33)$.

The enterotoxin genes A (sea), B (seb), C (sec) and D (sed) were detected in the two isolates of S. aureus (QCSA24 and QCSA34). Yoon et al. (29) reported that some S. aureus strains isolated from cheese are able to form four different serotypes of staphylococcal enterotoxins (SEs), sea, seb, sec and sed. The coalho goat cheese produced in the semi-arid northeast region of Brazil is a potential carrier of enterotoxigenic S. aureus.

\section{Protective activity and identification of autochthonous $L A B$}

There were observable differences in the inhibitory activity of the autochthonous $L A B(p<0.05)$ against the enterotoxigenic MDR S. aureus isolate (QCSA24, MAR index 0.91). Twenty-two $L A B$ isolates showed an ability to inhibit S. aureus (Fig. 2). Six isolates of $L A B$ from the municipalities of Petrolina (QC1 and QC4), Lagoa Grande (QC13 and QC14) and Cabrobó (QC18 and QC19) had pronounced inhibitory activity. These isolates were selected for subsequent testing of the ability to

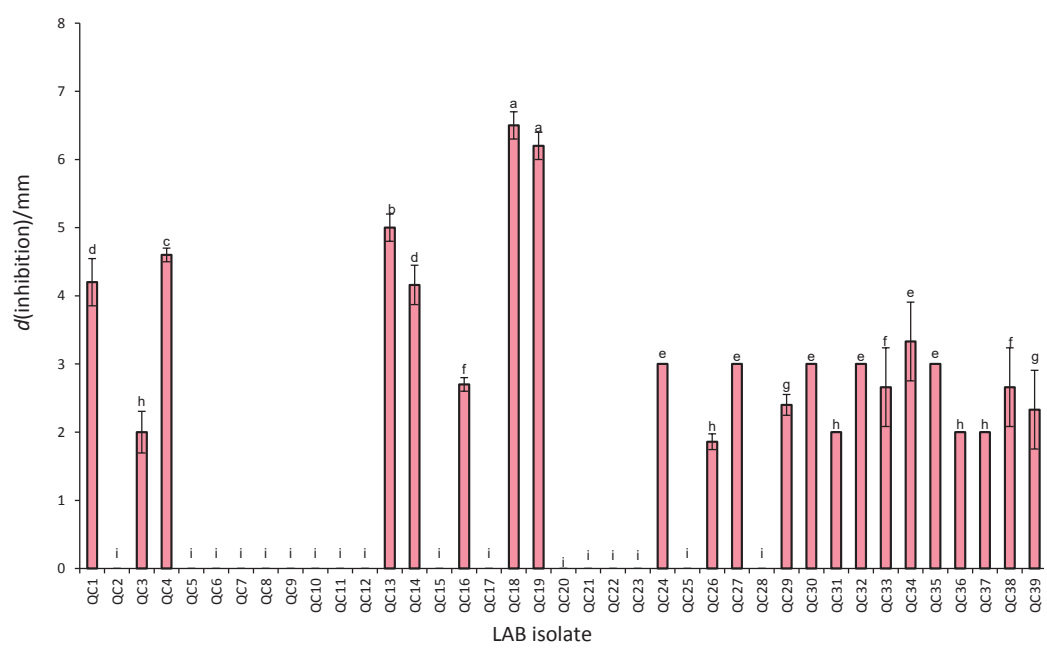

Fig. 2. Antimicrobial activity of the autochthonous lactic acid bacteria (LAB) isolates (UNIVASF CAP) against the enterotoxigenic multidrug resistant Staphylococcus aureus isolate (QCSA24) from coalho goat cheese. Values designated by different letters are significantly different $(p<0.05)$. Standard error $=0.122$ 
confer this inhibitory activity to artisanal cheese. According to Yoon et al. (29), LAB have been shown to inhibit the growth of $S$. aureus in cheese by the production of diacetyl, organic acids and bacteriocins.

Each autochthonous $L A B$ isolate was tested against another $L A B$ isolate to test the antimicrobial activity among them. None of the six selected LAB isolates exhibited the ability to inhibit another isolate. This finding is interesting for the use of these cultures together as inhibitors against $S$. aureus.

After the selection of autochthonous LAB with antibacterial activity against $S$. aureus and the observation of non-antagonism among them, they were subjected to molecular identification. These $L A B$ isolates were identified based on 16S rRNA gene sequence analysis with $99 \%$ similarity as Enterococcus faecium (NR_114742.1), which has been found in Brazilian artisanal cheese products (34).

\section{Virulence factors and technofunctional properties of autochthonous E. faecium}

For the characterization of virulence factors, the six tested $E$. faecium isolates were negative for haemolytic activity, production of DNase and ability to coagulate rabbit plasma (Table 4).

Another important criterion to be investigated is the antibiotic resistance of these strains. Antibiotic-sensitive $L A B$ have no contribution to horizontal transfer of antibiotic resistance genes to pathogenic bacteria. In this study, the strains showed high rates of susceptibility to antimicrobial agents (Table 4). Four enterococcal strains showed sensitivity to all investigated antibiotics. The strains E. faecium QC1 and QC19 were only resistant to oxacillin. Resistance to this antibiotic in E. faecium isolated from cheese was also verified by Amaral et al. (35). These authors reported that the resistance to oxacillin is an intrinsic feature of E. faecium, chromosomally encoded.

These four isolates also demonstrated high tolerance to low $\mathrm{pH}$ and bile salts. The survival rates under these conditions ranged from 95.6 to $99.1 \%$ and from 98.5 to $99.2 \%$, respectively (Table 4). The gastric emptying half time and the small bowel transit time in healthy women and men, in general, are estimated to be approx. $3 \mathrm{~h}$ (36). These criteria are important, since probiotic strains must be able to withstand $\mathrm{pH}$ variations and bile in the gastrointestinal tract. In addition, tolerance to low $\mathrm{pH}$ is also fundamental for the technological use of these cultures in cheese. Our results corroborate those of İspirli et al. (37); E. faecium isolated from cheese showed the ability to inhibit $S$. aureus and had technofunctional properties for use in cheese production.

The six isolates of E. faecium were positive for $\beta$-galactosidase and proteolytic activity (Table 4). Dos Santos et al. (34) also reported the isolation of E. faecium from Brazilian cheese with $\beta$-galactosidase and proteolytic activity. Cultures that have the ability to ferment lactose are very important for the dairy industry. Functionally, the hydrolysis of lactose allows cheese consumption by people intolerant to lactose.

\section{Inhibition of S. aureus growth by E. faecium in coalho goat cheese}

The milk used to produce the cheese was in accordance with the standard of identity and quality of product (32). After the thermal processing of milk, in the negative control cheese there was no detection of microorganisms. In the positive control cheese (SA), LAB were also not detected. Thus, only our selected Enterococcus inoculum was evaluated for the control of pathogenic $S$. aureus in coalho goat cheese.

There was correlation $(p<0.05)$ between the storage period and the count of S. aureus in all cheese samples (Table 5). A lower population of pathogens was present in the cheese inoculated with the mix of E. faecium (SA+LAB). Populations of $S$. aureus differed among cheese samples from the 5 th day of storage $(p<0.05)$.

In the positive control (SA), the regression equation showed that there was a decrease in the $S$. aureus population as a function of the storage period (Table 5). According to the regression equation, the lowest count was on day 16 , where the pathogen population measured $7.76 \mathrm{log}$ CFU/g. In general, there was a difference of 0.44 log units in the initial and final population of S. aureus in the positive control (SA). This small decrease might

Table 4. Safety, technological and functional properties of selected autochthonous Enterococcus faecium from coalho goat cheese

\begin{tabular}{|c|c|c|c|c|c|c|}
\hline \multirow{2}{*}{ Property } & \multicolumn{6}{|c|}{ Enterococcus faecium (UNIVASF CAP) } \\
\hline & QC1 & QC4 & QC13 & QC14 & QC18 & QC19 \\
\hline Haemolytic activity & - & - & - & - & - & - \\
\hline Production of DNase & - & - & - & - & - & - \\
\hline Coagulase activity & - & - & - & - & - & - \\
\hline Inhibition between LAB & - & - & - & - & - & - \\
\hline Susceptibility rate/\%* & 91.66 & 100 & 100 & 100 & 100 & 91.66 \\
\hline Resistance to antimicrobial agent* & oxacilin & - & - & - & - & oxacilin \\
\hline Survival rate to $\mathrm{pH}=2 / \%$ & 98.3 & 95.8 & 99.1 & 96.8 & 95.6 & 97.1 \\
\hline Survival rate to $2 \%$ bile salts $/ \%$ & 98.5 & 99 & 99.2 & 99 & 98.9 & 98.7 \\
\hline$\beta$-Galactosidase activity & + & + & + & + & + & + \\
\hline Proteolytic activity & + & + & + & + & + & + \\
\hline
\end{tabular}

*12 tested antimicrobials, $-=$ negative,$+=$ positive, $\mathrm{LAB}=$ lactic acid bacteria 
Table 5. The viable count (log CFU/g) of Staphylococcus aureus in the cheese samples (SA and SA+LAB) and of Enterococcus faecium in cheese sample $\mathrm{SA}+\mathrm{LAB}$ (with a mix of E. faecium UNIVASF CAP) during storage for up to 20 days at $10^{\circ} \mathrm{C}$

\begin{tabular}{|c|c|c|c|c|c|c|c|}
\hline \multirow{2}{*}{ Cheese sample } & \multicolumn{5}{|c|}{$t$ (storage)/day } & \multirow{2}{*}{ Log fold decrease day 0-20 } & \multirow{2}{*}{ Equation } \\
\hline & 0 & 5 & 10 & 15 & 20 & & \\
\hline \multicolumn{8}{|c|}{$N($ S. aureus $) /(\log \text { CFU/g })^{1}$} \\
\hline SA & $8.37^{\mathrm{a}}$ & $7.91^{\mathrm{a}}$ & $7.94^{\mathrm{a}}$ & $7.94^{\mathrm{a}}$ & $7.93^{\mathrm{a}}$ & 0.44 & $y=0.002 x^{2}-0.07 x+8.31 R^{2}=0.80$ \\
\hline $\mathrm{SA}+\mathrm{LAB} *$ & $8.39^{a}$ & $6.48^{\mathrm{b}}$ & $6.48^{\mathrm{b}}$ & $5.68^{\mathrm{b}}$ & $5.57^{\mathrm{b}}$ & 2.82 & $y=-0.14 x+7.81 R^{2}=0.80$ \\
\hline \multicolumn{6}{|c|}{$N($ E. faecium $) /(\log \text { CFU/g })^{2}$} & \multicolumn{2}{|l|}{ Log fold increase day 0-20 } \\
\hline $\mathrm{SA}+\mathrm{LAB} *$ & 8.50 & 9.43 & 9.76 & 9.93 & 9.91 & 1.41 & $y=0.07 x+8.846 R^{2}=0.77$ \\
\hline
\end{tabular}

For each column, mean values with different letters are significant $(\mathrm{p}<0.05)$ according to the Scott-Knott test, standard error $={ }^{1} 0.0384$ and ${ }^{2} 0.0245$ *Cheese with the inclusion of $E$. faecium mix, $\mathrm{SA}=S$. aureus, $\mathrm{LAB}=$ lactic acid bacteria

have been influenced by the storage temperature, in accordance with Jakobsen et al. (38).

There was a difference of 2.82 log units in the initial and final population of $S$. aureus in the cheese sample SA+LAB (Table 5). In this cheese, the population of S. aureus decreased 0.13 log units per day according to the first degree equation. During the assessment period, there was a reduction of approx. 3 log units of the S. aureus population. Sahraoui et al. (5) also reported an antagonistic effect of autochthonous Lactococcus strain from Algerian raw goat's milk against $S$. aureus. Inhibition of $S$. aureus by $L A B$ can be associated with acidification, bacteriocin and $\mathrm{H}_{2} \mathrm{O}_{2}$ production. Delpech et al. (39) confirmed that the growth of the foodborne pathogen $S$. aureus can be inhibited in milk and cheese by hydrogen peroxide-producing bacteria.

In relation to the population of selected Enterococcus from goat cheese, the inoculum increased linearly over time $(0.07 \mathrm{log}$ unit per day), as can be explained by the first degree equation (Table 5). The LAB population increased $1.41 \mathrm{log}$ units at the end of storage period (day 0 to day 20). The selected inoculum of $E$. faecium (UNIVASF CAP) and S. aureus originated from goat cheese. Our UNIVASF CAP isolates exhibited inhibition of S. aureus (isolate with highest MAR index) both in vitro and in the goat cheese product. Sahraoui et al. (5) confirmed that autochthonous $L A B$, in addition to their bioprotective effect, contribute to the terroir of the product and sustain the Protected Appellations of Origin of the cheese.

It is noteworthy that Enterococcus contributes to the development of the flavour of cheese $(26,37)$, improving the sensory acceptance of the goat product. In this study we reported an average of $6.2 \mathrm{log}$ CFU/g of S. aureus in coalho goat cheese commercialized in the semi-arid region. Thus, the addition of inoculum containing enterococci could be an option so that the product caters to Brazilian legislation by not containing enough pathogen population to produce enterotoxin. As previously discussed, a pathogen population greater than $4 \mathrm{log}$ CFU/g in milk and milk products is necessary for the production of enterotoxin. Thus, the inoculum constitutes an additional hurdle for the pathogen population in the product. Furthermore, the success for the prevention of $S$. aureus growth in cheese requires hygiene measures implemented along the entire production chain.

The $\mathrm{pH}$ in positive control (SA) changed following a quadratic equation (Fig. 3 ), with a higher value on the 12th day (6.77), and a minimum reduction at the end of storage. In cheese sample $\mathrm{SA}+\mathrm{LAB}$, the $\mathrm{pH}$ value decreased linearly over time by 0.05 units per day. Although S. aureus have bacterial proteases that induce proteolytic degradation, generating alkaline radicals, the $\mathrm{pH}$ decline can be explained by the production of organic acid by the UNIVASF CAP isolates.

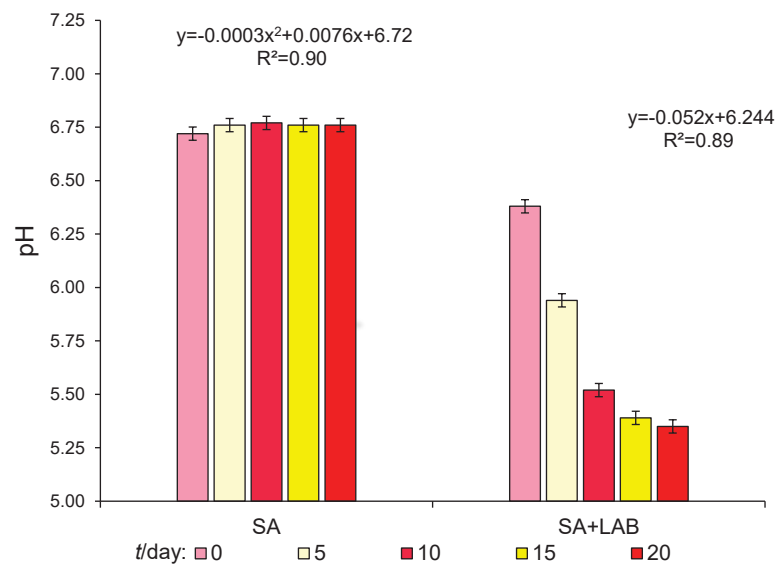

Fig. 3. $\mathrm{pH}$ values in cheese samples without $(\mathrm{SA})$ and with $(\mathrm{SA}+\mathrm{LAB})$ a mix of Enterococcus faecium during storage for up to 20 days at $10{ }^{\circ} \mathrm{C}$. Standard error $=0.031, \mathrm{SA}=$ Staphylococcus aureus, $\mathrm{LAB}=$ lactic acid bacteria

\section{CONCLUSIONS}

The cheese commercialized in the semi-arid northeastern region of Brazil is a pathogen vehicle. Multidrug resistant (MDR) strains of Escherichia coli, Staphylococcus aureus, Listeria and Salmonella are circulating in the product. The pathogen most commonly present in coalho goat cheese was Staphylococcus. However, this study demonstrated that selected autochthonous lactic acid bacteria (LAB) from goat cheese (UNIVASF (AP), identified as Enterococcus faecium, were able to reduce approx. 3 log units of the enterotoxigenic MDR S. aureus isolated from coalho goat cheese. These autochthonous $\mathrm{LAB}$ cultures, which are particular biotype of a geographical area, ensure a differentiated coalho goat cheese, exclusive to the region of origin. In addition, these cultures can contribute to increasing the sensory and functional properties of the artisanal goat cheese. Thus, the selected LAB inoculum could be an option for smallholders to produce cheese with a higher microbiological quality by applying good farming and processing practices, such as using milk of good quality and following proper hygiene procedures during cheese-making. 


\section{ACKNOWLEDGEMENTS}

The authors wish to acknowledge the FACEPE (Fundação de Amparo à Ciência e Tecnologia do Estado de Pernambuco) for financial support and scholarship, and the FIOCRUZ (Fundação Oswaldo Cruz) for the donation of S. aureus strains (INCQS 00285, INCQS 00005, INCQS 00080 and INCQS 00093).

\section{REFERENCES}

1. Mourão Cavalcante JF, de Andrade NJ, Mansur Furtado M, de Luces Fortes Ferreira $\mathrm{CL}$, de Oliveira Pinto $\mathrm{CL}$, Elard $\mathrm{E}$. Manufacture of regional coalho type cheese by using pasteurized and standardized cow milk with added endogenous lactic acid culture. Ciênc Tecnol Aliment. 2007; 27(1): 205-14 (in Portuguese).

https://doi.org/10.1590/S0101-20612007000100036

2. Queiroga RCRE, Santos BM, Gomes AMP, Monteiro MJ, Teixeira SM, de Souza EL, et al. Nutritional, textural and sensory properties of Coalho cheese made of goats', cows' milk and their mixture. LWT-Food Sci Technol. 2013;50(2):538-44.

https://doi.org/10.1016/j.lwt.2012.08.011

3. Ramírez-Rivera EJ, Ramón-Canul LG, Díaz-Rivera P, JuárezBarrientos JM, Herman-Lara E, Prinyawiwatkul W, HerreraCorredor JA. Sensory profiles of artisan goat cheeses as influenced by the cultural context and the type of panel. Int J Food Sci Technol. 2017;52(8):1789-800.

https://doi.org/10.1111/ijfs.13452

4. Oliveira CJB, Hisrich ER, Moura JFP, Givisiez PEN, Costa RG, Gebreyes WA. On farm risk factors associated with goat milk quality in Northeast Brazil. Small Rumin Res. 2011;98(1-3): 64-9.

https://doi.org/10.1016/j.smallrumres.2011.03.020

5. Sahraoui Y, Fayolle K, Leriche F, Le Flèche-Matéos A, Sadoun D. Antibacterial and technological properties of Lactococcus lactis ssp. lactis KJ660075 strain selected for its inhibitory power against Staphylococcus aureus for cheese quality improving. J Food Sci Technol. 2015;52(11):7133-42. https://doi.org/10.1007/s13197-015-1845-9

6. Basanisi MG, Nobili G, La Bella G, Russo R, Spano G, Normanno G, La Salandra G. Molecular characterization of Staphylococcus aureus isolated from sheep and goat cheeses in southern Italy. Small Rumin Res. 2015;135:17-9.

https://doi.org/10.1016/j.smallrumres.2015.12.024

7. Pappa EC, Bontinis TG, Tasioula-Margari M, Samelis J. Microbial quality of and biochemical changes in fresh soft, acid-curd Xinotyri cheese made from raw or pasteurized goat's milk. Food Technol Biotechnol. 2017;55(4):496-510. https://doi.org/10.17113/ftb.55.04.17.5338

8. de Souza JV, Dias FS. Protective, technological, and functional properties of select autochthonous lactic acid bacteria from goat dairy products. Curr Opin Food Sci. 2017;13:1-9.

https://doi.org/10.1016/j.cofs.2017.01.003
9. Regulation of the procedures for artisanal cheese production. Normative Instruction no. 30, 7 August 2013. Official Journal of the Federal Government of Brazil. Brasília, Federal District, Section 1, Brazil: Ministry of Agriculture, Livestock and Supply; 2013 (in Portuguese).

10. Merck Microbiology Manual. Berlin, Germany: Merck; 2002.

11. Official analytical methods for the control of products of animal origin and water. Normative Instruction no. 62, 26 August 2003. Official Journal of the Federal Government of Brazil. Brasília, Federal District, Section 1, Brazil: Ministry of Agriculture, Livestock and Supply; 2003 (in Portuguese).

12. Pignato S, Marino AM, Emanuele MC, lannotta V, Caracappa $\mathrm{S}$, Giammanco G. Evaluation of new culture media for rapid detection and isolation of salmonellae in foods. Appl Environ Microbiol. 1995;61(5):1996-9.

13. Capita R, Alonso-Calleja C, Prieto M, García-Fernández MC, Moreno B. Comparison of PALCAM and modified Oxford plating media for isolation of Listeria species in poultry meat following UVM II or Fraser secondary enrichment broths. Food Microbiol. 2001;18:555-63.

https://doi.org/10.1006/fmic.2001.0446

14. de Almeida Júnior WLG, Ferrari IDS, Souza JV, da Silva CDA, da Costa MM, Dias FS. Characterization and evaluation of lactic acid bacteria isolated from goat milk. Food Control. 2015;53:96-103.

https://doi.org/10.1016/j.foodcont.2015.01.013

15. Performance standards for antimicrobial susceptibility testing; twenty-second informational supplement. CLSI document M100-S22. Vol. 32(3). Wayne, PA, USA: Clinical and Laboratory Standards Institute (CLSI); 2012.

16. Hanon JB, Jaspers S, Butaye P, Wattiau P, Méroc E, Aerts M, et al. A trend analysis of antimicrobial resistance in commensal Escherichia coli from several livestock species in Belgium (2011-2014). Prev Vet Med. 2015;122(4):443-52.

https://doi.org/10.1016/j.prevetmed.2015.09.001

17. de Ávila ARA, Marques SC, Piccolli RH, Schwan RF. Sensitivity to organic acids in vitro and in situ of Salmonella spp. and Escherichia coli isolated from fresh pork sausages. J Food Qual. 2013;36(3):155-63.

https://doi.org/10.1111/jfq.12026

18. Schneid Kroning I, Iglesias MA, Sehn CP, Gandra TKV, Mata MM, da Silva WP. Staphylococcus aureus isolated from handmade sweets: Biofilm formation, enterotoxigenicity and antimicrobial resistance. Food Microbiol. 2016;58:105-11. https://doi.org/10.1016/j.fm.2016.04.001

19. Ferrari IS, de Souza JV, Ramos CL, da Costa MM, Schwan RF, Dias FS. Selection of autochthonous lactic acid bacteria from goat dairies and their addition to evaluate the inhibition of Salmonella typhi in artisanal cheese. Food Microbiol. 2016;60:29-38. https://doi.org/10.1016/j.fm.2016.06.014

20. Brink M, Todorov SD, Martin JH, Senekal M, Dicks LMT. The effect of prebiotics on production of antimicrobial 
compounds, resistance to growth at low $\mathrm{pH}$ and in the presence of bile, and adhesion of probiotic cells to intestinal mucus. J Appl Microbiol. 2006;100(4):813-20. https://doi.org/10.1111/j.1365-2672.2006.02859.x

21. Ferreira DF. Sisvar: A computer statistical analysis system. Ciênc Agrotecnol. 2011;35(6):1039-42.

22. Scott AJ, Knott, M. A cluster analysis method for grouping means in the analysis of variance. Biometrics. 1974;30(3): 507-12.

23. Technical regulation for identity and quality of coalho cheese. Normative Instruction no. 30, 25 April 2001. Official Journal of the Federal Government of Brazil. Brasília, Federal District, Section 1, Brazil: Ministry of Agriculture, Livestock and Supply; 2001 (in Portuguese).

24. El Galiou O, Zantar S, Bakkali M, Laglaoui A, Centeno JA, Carballo J. Chemical and microbiological characteristics of traditional homemade fresh goat cheeses from Northern Morocco. Small Rumin Res. 2015;129:108-13.

https://doi.org/10.1016/j.smallrumres.2015.06.005

25. Picon A, Garde S, Ávila M, Nuñez M. Microbiota dynamics and lactic acid bacteria biodiversity in raw goat milk cheeses. Int Dairy J. 2015;58:14-22.

https://doi.org/10.1016/j.idairyj.2015.09.010

26. Favaro L, Basaglia M, Casella S, Hue I, Dousset X, Franco BDGM, Todorov SD. Bacteriocinogenic potential and safety evaluation of non-starter Enterococcus faecium strains isolated from home made white brine cheese. Food Microbiol. 2014;38:228-39.

https://doi.org/10.1016/j.fm.2013.09.008

27. Technical regulation on microbiological standards for foods. Annexes I and II. Resolution RDC no. 12, 2 January 2001. Official Journal of the Federal Government of Brazil. Brasília, Federal District, Section 1, Brazil: Brazilian Health Regulatory Agency; 2001 (in Portuguese).

28. Technical regulation for identity and quality of cheese. Annex II - General technical regulation for the establishment of the microbiological requirements of cheese. Ordinance no. 146, 7 March 1996. Official Journal of the Federal Government of Brazil. Brasília, Federal District, Section 1, Brazil: Ministry of Agriculture, Livestock and Supply; 1996 (in Portuguese).

29. Yoon Y, Lee S, Choi KH. Microbial benefits and risks of raw milk cheese. Food Control. 2016;63:201-15.

https://doi.org/10.1016/j.foodcont.2015.11.013
30. Kousta M, Mataragas M, Skandamis P, Drosinos EH. Prevalence and sources of cheese contamination with pathogens at farm and processing levels. Food Control. 2010;21(6):805-15. https://doi.org/10.1016/j.foodcont.2009.11.015

31. Melo J, Andrew PW, Faleiro ML. Listeria monocytogenes in cheese and the dairy environment remains a food safety challenge: The role of stress responses. Food Res Int. 2015; 67:75-90. https://doi.org/10.1016/j.foodres.2014.10.031

32. Technical regulation for identity and quality of goat's milk. Normative Instruction no. 37, 31 October 2000. Official Journal of the Federal Government of Brazil. Brasília, Federal District, Section 1, Brazil: Ministry of Agriculture, Livestock and Supply; 2000 (in Portuguese).

33. Colak $\mathrm{H}$, Hampikyan $\mathrm{H}$, Bingol EB, Ulusoy B. Prevalence of L. monocytogenes and Salmonella spp. in Tulum cheese. Food Control. 2007;18(5):576-9. https://doi.org/10.1016/j.foodcont.2006.02.004

34. dos Santos KM, Vieira ADS, Salles HO, Oliveira JS, Rocha $\mathrm{CR}$, Borges MF, et al. Safety, beneficial and technological properties of Enterococcus faecium isolated from Brazilian cheeses. Braz J Microbiol. 2015;46(1):237-49.

https://doi.org/10.1590/S1517-838246120131245

35. Amaral DMF, Silva LF, Casarotti SN, Nascimento LCS, Penna ALB. Enterococcus faecium and Enterococcus durans isolated from cheese: Survival in the presence of medications under simulated gastrointestinal conditions and adhesion properties. J Dairy Sci. 2017;100(2):1-17. https://doi.org/10.3168/jds.2016-11513

36. Degen, LP, Phillips SF. Variability of gastrointestinal transit in healthy women and men. Gut. 1996;39(2):299-305.

37. İspirli H, Demirbaş F, Dertli E. Characterization of functional properties of Enterococcus spp isolated from Turkish white cheese. LWT - Food Sci Technol. 2017;75:358-65.

https://doi.org/10.1016/j.lwt.2016.09.010

38. Jakobsen RA, Heggebø R, Sunde EB, Skjervheim M. Staphylococcus aureus and Listeria monocytogenes in Norwegian raw milk cheese production. Food Microbiol. 2011;28(3): 492-6. https://doi.org/10.1016/j.fm.2010.10.017

39. Delpech P, Bornes S, Alaterre E, Bonnet M, Gagne G, Montel $M$, Delbès $C$. Staphylococcus aureus transcriptomic response to inhibition by $\mathrm{H}_{2} \mathrm{O}_{2}$-producing Lactococcus garvieae. Food Microbiol. 2015;51:163-70.

https://doi.org/10.1016/j.fm.2015.05.014 